\title{
Studies on Performance of Different Type of Hand Protection Devices on Women Workers for Fish Dressing Operation in Seafood Processing Industries
}

\author{
S.M. Shaikh ${ }^{1}$, A.U. Pagarkar ${ }^{2}$ and Abhay Kumar $^{3}$ \\ ${ }^{1}$ College of Fisheries, Shirgaon (Dr. B. S. Konkan Krishi Vidyapeeth, Dapoli), \\ Ratnagiri - 415 629, India \\ ${ }^{2}$ Marine Biological Research Station (Dr. B. S. Konkan Krishi Vidyapeeth, Dapoli), \\ Ratnagiri - 415 612, India \\ ${ }^{3}$ Mumbai Research Centre of CIFT, Vashi, Navi Mumbai-400703, India \\ *Corresponding author
}

\section{A B S T R A C T}

\section{Keywords}

Hand protection devices, Gloves,

Fish dressing,

Ergonomics in fish processing

\section{Article Info}

Accepted:

07 October 2019

Available Online:

10 November 2019
Currently, fish consumption is growing worldwide, especially due to the demand for healthier foods and also the improvement of processes, increasing the shelf life and providing easiness in the preparation and consumption of these products. The fisheries sector is a powerful income and employment generation for maritime nation. Fish dressing operation is one of the most important operations in fish processing industry. However, doing various fish dressing operations several occupational health problems such as injuries, skin and respiratory allergic manifestations occurs among fish processing workers. These occupational health problems result in increased incapacity and absenteeism among affected workers. To prevent these problems, performance and suitability of five different types of hand protection devices viz., finger coats, medical examination, sterile surgical, cotton and combination of medical examination and cotton gloves on women workers were tested during fish dressing operation. The present study subjected to ten female workers. The highest mean working capacity was found for combination of medical examination gloves (in side) and cotton gloves (outside) as 42.4 $\mathrm{kg} / \mathrm{hr}(\mathrm{P}<0.05)$ with more acceptability, very fast to work, no injuries in hands. The significant difference $(\mathrm{p}<0.05)$ was observed among different types of hand protection. Hence, the present study suggest that combination of medical examination gloves (in side) and cotton gloves are better as a first line of defense in order to protect the hand from ice and cold water shocks, injuries and peeing of hand during fish dressing operation.

\section{Introduction}

In recent years, a tremendous growth in aquaculture and fisheries sector of India, So fish processing and seafood industries mainly increasing supply and demand for seafood products. However, this increase in supply and demand led to increased levels of seafood 
production and processing of seafood, causing much more stress on the seafood industries manpower and its infrastructure to meet the consumer demands. This stress lead to increase in occupational health problems such as injuries, skin and respiratory allergic manifestations and certain other diseases among seafood processing workers. These occupational health problems result in increased incapacity and absenteeism among affected workers. In seafood industry mostly women workers getting more affected as a result of differences in physical exposures and psychosocial work environments (Shaikh et al., 2016).

In fish processing industries various processing operations are involved such as peeling, grading, deveining, packing and freezing. Mostly all of these operations are manually carried out by women workers in which there are more chances of injuries to the hand due to cold shocks, cuts from fish spines, knifes etc. Exposure to cold environments and contact with cold materials have been reported impair tactile sensitivity in the hands (Enander, 1984), hand dexterity (Schiefer et al., 1984; Riley and Cochran, 1984; Enander and Hygge, 1990; Heuset al., 1995), and tracking performance (Goonetilleke and Hoffmann, 2009). According to Nag et al., (2007), numbness of hand and dexterity reacting badly on palm and skin of hands of women workers during fish dressing operations. Occupational health problems including musculo-skeletal pain and discomfort among the fish processing workers has been already highlighted (Olafsdottir and Rafnsson 2000; Chiang et al., 1993; Nordander et al., 1999; Ohlsson et al., 1994). In recent times some researchers also reported occupational injury occurrence due to poor work environmental conditions. (Bhattacherjee et al., 2003; Ghosh et al., 2004)
Presently women workers in most of fish dressing industries are not using any hand protection devices. To protect hands form cold and injuries, gloves are recommended as a first line of defence. Wearing gloves can not only reduce pain but also delay a decrease in finger skin temperature (FST) (Suizu and Harada, 2005).According to (Nag, 2007) use of gloves most of the workers reported a feeling of comfort and protection from direct contact with ice-cold chlorinated water. In order to protect the hand from ice and cold water, injuries and peeing of hand, surgical gloves are recommended as a first line of defense (Pagarkar et al., 2014). However, the performance of the use of any hand protection devices in fish dressing operation can be considerably improved through ergonomic aspects. The application of ergonomics can help in increasing the efficiency and thereby productivity of the workers without jeopardizing their health and safety.

In Konkan region of Maharashtra, there are many fish processing industry operating along the coastal region. Along the Ratnagiri coast, mostly the bulk catch of shrimps, sardine, mackerel, ribbion fish, pink perch occurs. Due to low cost and bulk availability, fishes such as sardine, pink perch are mostly utilized for surimi preparation in many fish processing units of Ratnagiri. Another peculiar feature of such fish processing industries is that only women workers are employed for the job of fish processing operations i.e. (cutting)/peeling/ring cutting, grading, packing etc. For dressing / cutting of the fish, mostly small hand tools like knives and the needles are used by women workers. However, due to the non availability of good quality facilities i.e. gloves, protection devices, etc these workers faces many injuries during fish dressing operation which lead to serious health problems, increased incapacity and absenteeism affecting both production and workers overall health. Keeping in view the 
need of hand protection devices and to check their suitability in fish dressing operation for woman labour, the present investigation was undertaken to obtain information on performance of different hand protection devices on women workers used during fish dressing operations.

\section{Materials and Methods}

The study was carried out in fish dressing unit of Maharashtra during 2016. Primary data was collected from the workers involved in fish dressing unit through a structured questionnaire. This study was carried out in a mystery fish dressing unit section situated in Ratnagiri district of Maharashtra, India. During the study, Lesser Sardine, Sardinella fimbriata size ranges from (length 13.0 to 15.7 $\mathrm{cm}$ and weight 36.25 to $38.42 \mathrm{gm}$ ) was available and daily around 5 tonnes of Lesser Sardine fish were dressed in the preprocessing unit. In all, 30 women respondents working in fish dressing were interviewed. Percentages and averages have been used for analysing the employment status of the workers.

Pearson correlation model was used for determining the functional relationship between the socio-economic parameters and work participation (Almazan et al., 2011). The binary logistic regression model was carried out to assess the factors influencing employment (Kouser et al., 2012; Tinashe et al., 2013; Jeyanthi et al., 2015). The variables; age, height, weight, marital status education, work experience, headache and body ache and skin related problems were taken into account for the analysis. The mathematical derivation of the model is;

$$
\begin{aligned}
& Z i=L O G\left(\frac{P i}{1-P i}\right) \\
& \mathrm{Z}_{\mathrm{i}}=\alpha_{0}+\alpha_{1} \mathrm{X}_{1}+\alpha_{2} \mathrm{X}_{2}+\alpha_{3} \mathrm{X}_{3}+\alpha_{4} \mathrm{X}_{4}+\alpha_{5} \mathrm{X}_{5}+\alpha_{6} \mathrm{X}_{6}+\mathrm{e}
\end{aligned}
$$

Where,

$\mathrm{Z}_{\mathrm{i}}=$ binary dependent variable $(1=$ Processing workers and $0=$ Pre-processing workers)

$\mathrm{X}_{1}=$ age of the respondent

$\mathrm{X}_{2}=$ education status of the respondent

$\mathrm{X}_{3}=$ marital status of the respondent

$\mathrm{X}_{4}=$ family size of the respondent

$\mathrm{X}_{5}=$ work experience of the respondent

$\mathrm{X}_{6}=$ present wages of the respondent

$\mathrm{e}=$ error term

In the selected fish dressing unit, total 30 women workers were engaged used in fish dressing operation. All the women workers were interviewed with the help of questionnaire to collect information regarding their personal, occupational and work related morbidity details. After that only ten female subjects (workers) were selected randomly from all the workers for the investigation on performance suitability of different types of hand protection gloves. The physiological characteristics of selected subjects are given in Table 1. The five different types of hand protection devices viz., finger coats (A), medical examination gloves (B), sterile surgical gloves (C), cotton gloves (D) and combination of medical examination (in side) + cotton gloves (outer side) (E) were tested to check the performance and suitability of different types of hand protection devices during fish dressing operation. The details of the hand protection devices are given in Table 2. All the subjects were equally trained in dressing of fish operation. The fish dressing operation was carried out at a low room temperature. The dressing operation was conducted on modified traditional fish dressing method consisting of G.I. pipe elevated frame having arrangement for keeping one plastic crate for whole fish and other crate for dressed fish and in between sharp stainless steel knives was fitted for fish cutting purpose. Separate crate was kept for collection of fish waste and one crate was used 
for setting. The crate size was $650 \times 450 \times$ $315 \mathrm{~mm}$. Data obtained from the experiment were analysed to test significant difference by one way ANOVA. The significant differences were tested by 5\% level of significances difference (Zar, 2005).

\section{Results and Discussion}

Among 30 women workers in the selected fish dressing unit, $26.66 \%$ women workers were in the age group of $\leq 25$ years and $73.33 \%$ were above $\geq 25$ years. $56.66 \%$ women workers have height $\leq 5.2$ feet and $43.33 \%$ have height $\geq 5.2$ feet. In $36.66 \%$ women workers weight was reported $\leq 40 \mathrm{~kg}$ weight group and $63.33 \%$ of women workers were found $\geq 40 \mathrm{~kg}$ weight group.

During investigation, it was also found that $73.33 \%$ women workers have experience $\leq 10$ years and $26.66 \%$ women workers $\geq 10$ year experience. $83.33 \%$ women workers were illiterate against $16.66 \%$ literate women workers. Whereas $80 \%$ women workers were married and $20 \%$ women workers were unmarried. Regarding studies on health problems of women workers revealed that all workers were suffering from back pain (100\%), headache and body ache (96.66\%), skin related problems, $(70 \%)$, as common work related symptoms (Table 3 ).

In case of the ten selected subjects for fish dressing operation it was observed that $80 \%$ were literate and $20 \%$ illiterate. Whereas $70 \%$ married the rest $30 \%$ were unmarried and they had good $(100 \%)$ health status. Around $90 \%$ of the workers from ten selected subjects had initial hand injuries. The mean age, height, weight and experience of the selected ten subjects was $34.8 \pm 9.50$ years, $4.86 \pm 0.23$ feet, $50.4 \pm 9.17 \mathrm{~kg}$ and $8.4 \pm 6.8$ years, respectively.

Saha et al., (2006) observed in a survey of fish processing industry of western India involving
185 randomly selected women subjects. The mean age of the study subjects was 24.4 ( \pm 7.4) years. One hundred and thirty two $(71.4 \%)$ workers were $\leq 25$ years old and 53 (28.6) workers were more than 25 years old.

Mean job duration of the subjects was $3.8( \pm$ 3.3) years. Almost $80 \%$ workers had job experience of $\leq 5$ years. Ninety five percent subjects were educated, while $5 \%$ were illiterate. One hundred and nine workers $(58.9 \%)$ were unmarried.

Chiang et al., (1993) reported a high occurrence of pain or reported symptoms in the neck and shoulder (49.1\%) and arms and hands $(59.8 \%)$ of slaughterhouse workers. Ohlssonet al., (1989) reported that neck pain (39\%), shoulder pain $(55 \%)$, pain in elbows (21\%), and pain in hands $(43 \%)$ were the major musculoskeletal problems among female workers in fish processing industry.

Nag and Nag et al., (2007) reported the high prevalence of musculo-skeletal pain and discomfort among these women (67\%). The lower back (45\%) is the most affected area, followed by the shoulder $(20 \%)$ and upper back $(25 \%)$. The cold induced blanching and numbness of hands (61\%) were observed among the women workers.

To assess the relation of women workers with age, height, weight, marital status education, work experience, headache and body ache and skin related problems and blanching of hand, Pearson correlation co-efficient was carried out. The results showed that the women workers was positively correlated with age and height but negatively correlated with weight, marital status, education, work experience, headache and body ache and skin related problems. It was observed that weight, marital status and skin related problems were positively correlated and education, work experience and headache and body ache which 
is negatively correlated. Therefore, education, work experience and headache and body ache was positively correlated and headache and body ache and skin related problems also positively correlated (Table 4).

It was observed from the binary logistic results that employment in fish dressing units was positively influenced by height, weight, marital status education, work experience and present wages and the major determinants of employment were height, weight and wages in the fish dressing sector (Table 5).

Fish dressing capacity without hand protection gloves

The mean working capacity of ten selected subjects for fish dressing without use of different type of hand protection devices was $36.55 \mathrm{~kg} / \mathrm{hr}$. The maximum capacity was found for subject-1 at $45 \mathrm{~kg} / \mathrm{hr}$, whereas subject-4 showed lowest capacity at $30 \mathrm{~kg} / \mathrm{hr}$ for fish dressing without use of different type of hand protection devices (Fig. 1).

During dressing operation, it was observed that workers hand get frequent contact with low temperature of work environment and ice cold chlorinated water blanched of hand the workers hands.

The workers hands became more slippery due mucus from fish surface. The combine effects of workplace, leads frequent hand injuries, respiratory irritation (frequent sneezing and/or coughing) at work, headache, etc. (Nag and Nag, 2007; Pagarkar et al., 2014).

Table.1 Subjects information, health status and dressing capacity without hand protection devices

\begin{tabular}{|c|c|c|c|c|c|c|c|c|c|}
\hline 苞 & 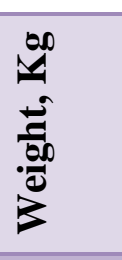 & 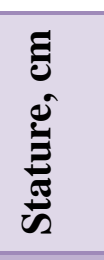 & 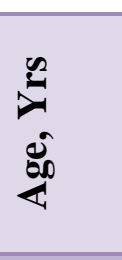 & 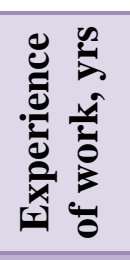 & 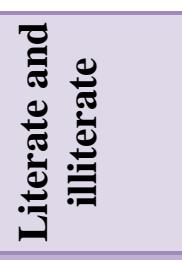 & 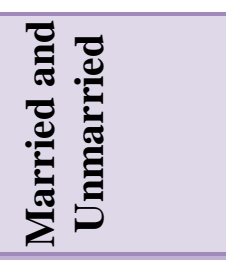 & 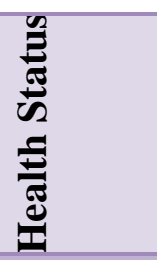 & 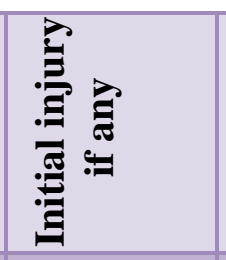 & 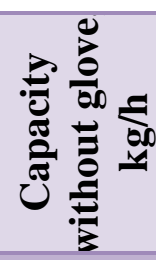 \\
\hline Subject 1 & 45 & 5.3 & 35 & 6 & 9 & Married & good & No & 45.00 \\
\hline Subject 2 & 57 & 4.9 & 45 & 20 & 0 & Married & good & No & 37.5 \\
\hline Subject 3 & 50 & 4.7 & 23 & 2 & 7 & Unmarried & good & No & 34.00 \\
\hline Subject 4 & 39 & 4.7 & 45 & 8 & 0 & Married & good & No & 30.00 \\
\hline Subject 5 & 38 & 5.1 & 19 & 2 & 7 & Unmarried & good & No & 43.00 \\
\hline Subject 6 & 53 & 5 & 35 & 3 & 9 & Married & good & No & 32.00 \\
\hline Subject 7 & 70 & 4.5 & 26 & 3 & 9 & Unmarried & good & No & 36.00 \\
\hline Subject 8 & 57 & 4.7 & 40 & 3 & 6 & Married & good & No & 37.00 \\
\hline Subject 9 & 46 & 4.8 & 39 & 25 & 7 & Married & good & No & 34.00 \\
\hline Subject 10 & 49 & 4.9 & 41 & 12 & 7 & Married & good & No & 37.00 \\
\hline Mean & 50.40 & 4.86 & 34.80 & 8.4 & 6.1 & -- & -- & -- & 36.55 \\
\hline $\mathrm{SD} \pm$ & 9.50 & 0.23 & 9.17 & 8.15 & 3.38 & -- & -- & -- & 4.60 \\
\hline$\%$ & -- & -- & -- & -- & $\begin{array}{c}\text { Literate } \\
\mathbf{8 0 \%}\end{array}$ & $\begin{array}{c}\text { Married } \\
\mathbf{7 0 \%}\end{array}$ & $100 \%$ & $100 \%$ & -- \\
\hline$\%$ & -- & -- & -- & -- & $\begin{array}{c}\text { Illiterate } \\
\mathbf{2 0 \%}\end{array}$ & $\begin{array}{c}\text { Unmarried } \\
\mathbf{3 0 \%}\end{array}$ & $\begin{array}{l}\text { Good } \\
\text { Health }\end{array}$ & No injuries & -- \\
\hline
\end{tabular}




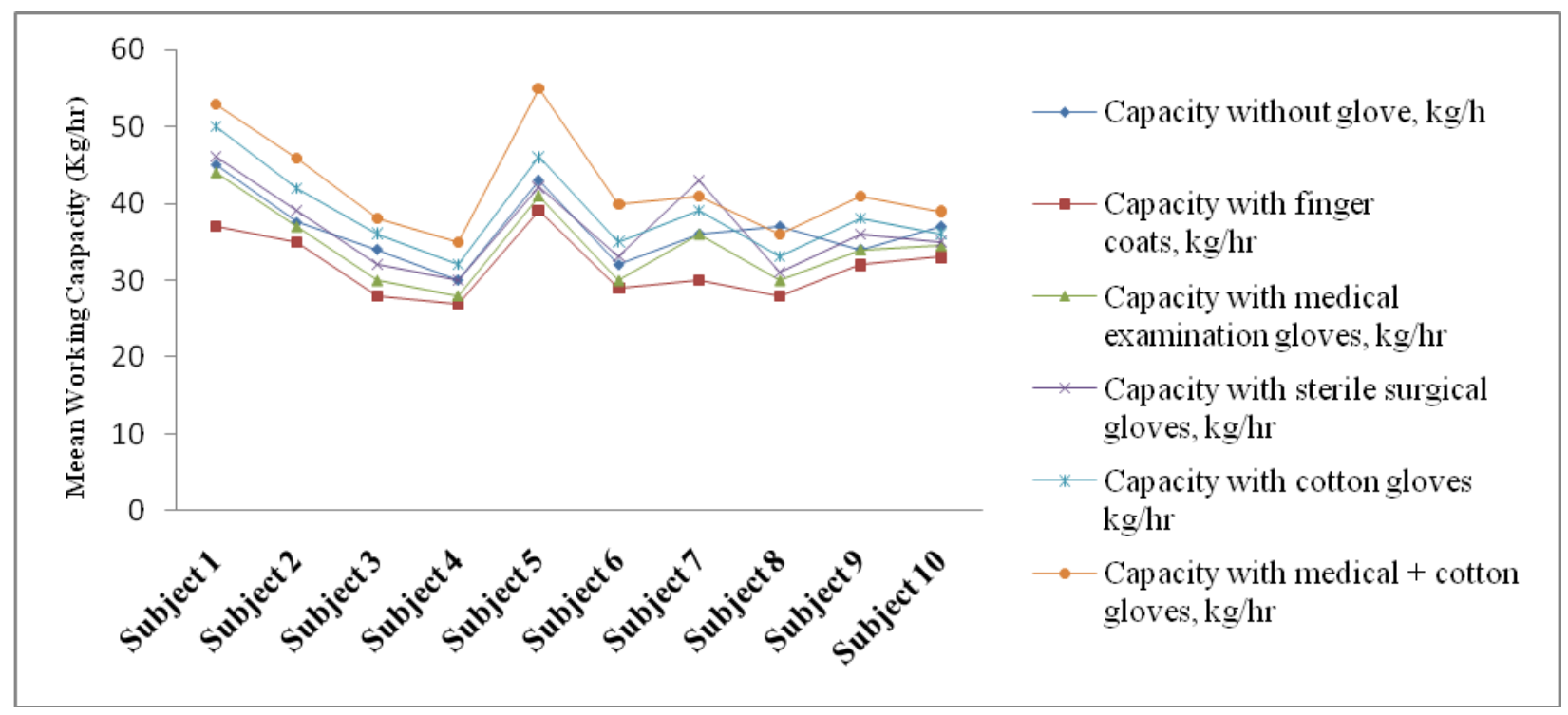

Fig.1 Working capacity $(\mathrm{kg} / \mathrm{hr})$ performance of women workers with and without hand protection devices during fish dressing operation.

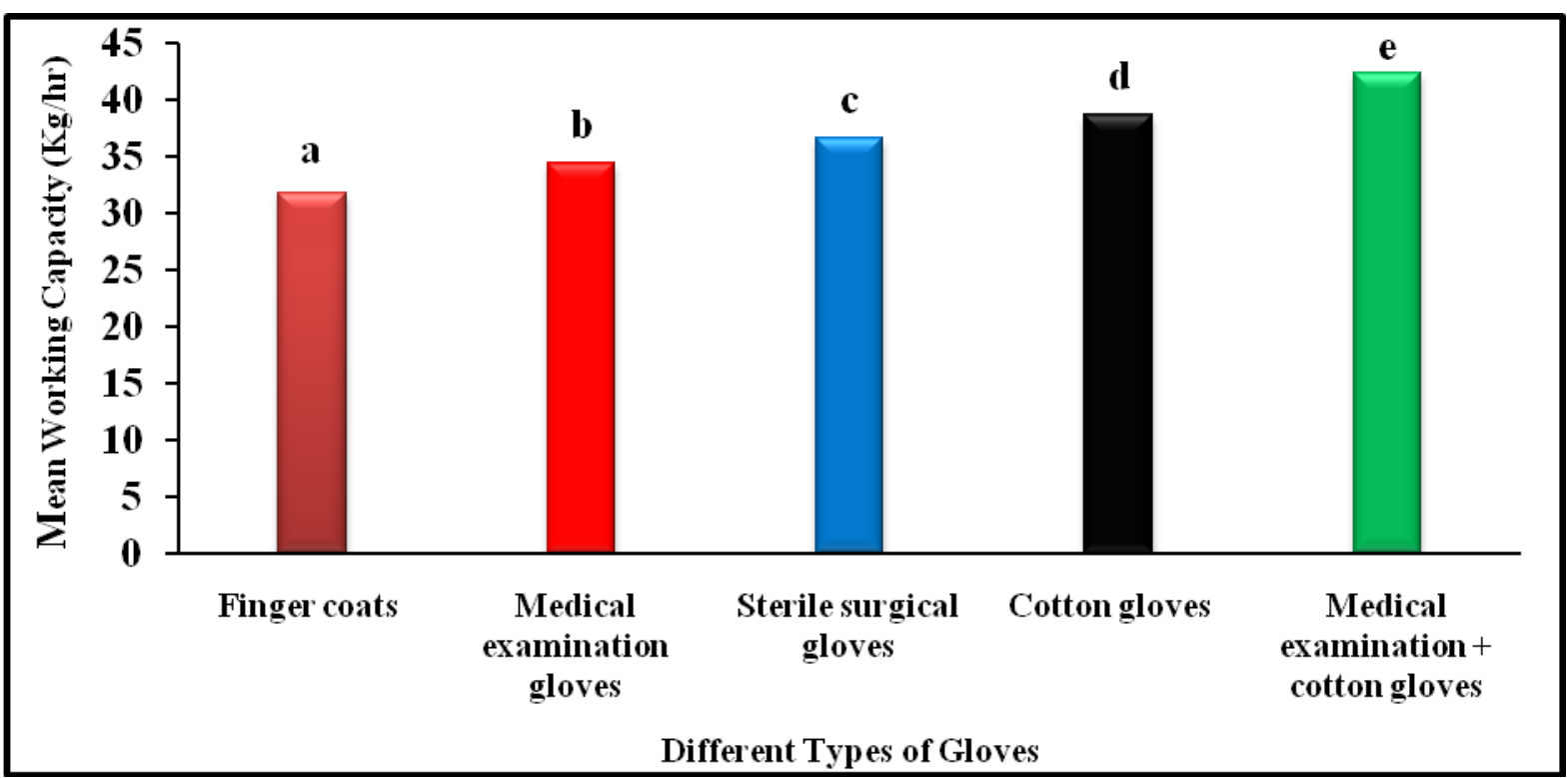

Fig.2 Mean working capacity $(\mathrm{kg} / \mathrm{hr})$ performance of women workers with hand protection devices during fish dressing operation 
Table.3 Specifications of hand protecting devices used in fish dressing operation

\begin{tabular}{|l|c|c|}
\hline Type of hand protecting devices & Material & Manufacturer Address \\
\hline Finger coat & Rubber & M/S Locally available \\
\hline Medical examination gloves & $\begin{array}{c}\text { Latex medical examination } \\
\text { rubber }\end{array}$ & $\begin{array}{c}\text { M/S Nulife Global Medical } \\
\text { Devices Pvt.Ltd. } \text { B }_{6} / B_{5}, \\
\text { Byculla service ind, D.K. } \\
\text { Marg, Byculla (E), Mumbai- } \\
\text { 27.India }\end{array}$ \\
\hline Sterile Surgical gloves & Rubber & $\begin{array}{c}\text { M/S Latex Surgical Gloves } \\
\text { B }_{4} / \text { B }_{5} \text { Byculla service Ind, } \\
\text { D.K. Marg, Byculla Mumbai- }\end{array}$ \\
\hline Cotton gloves & & 27.India \\
\hline
\end{tabular}

Table.4 Survey of women workers for identifying occupational health hazards in fish dressing unit

\begin{tabular}{|l|l|l|}
\hline Sr. No & Subject detail & Percentage \\
\hline $\mathbf{1}$ & Age (year) & \\
\hline & $\leq 25$ & 26.67 \\
\hline & $\geq 25$ & 73.33 \\
\hline $\mathbf{2}$ & Height (feet) & \\
\hline & $\leq 5.2$ & 56.66 \\
\hline & $\geq 5.2$ & 43.33 \\
\hline $\mathbf{3}$ & Weight (kg) & \\
\hline & $\leq 40$ & 36.66 \\
\hline & $\geq 40$ & 63.33 \\
\hline $\mathbf{4}$ & Experience(Years) & \\
\hline & $\leq 10$ & 73.33 \\
\hline & $\geq 10$ & 26.66 \\
\hline $\mathbf{5}$ & Educational status & \\
\hline & Illiterate & 16.67 \\
\hline & Educated & 83.33 \\
\hline $\mathbf{6}$ & Marital status & \\
\hline & Married & 80.00 \\
\hline & Unmarried & 20.00 \\
\hline $\mathbf{7}$ & Work related morbidity & \\
\hline & Headache and body ache & 96.67 \\
\hline & Skin related problem & 70.00 \\
\hline & & \\
\hline
\end{tabular}


Table.5 Pearson correlation matrix of workers in the fish dressing unit

\begin{tabular}{|c|c|c|c|c|c|c|c|c|}
\hline Particulars & Age & Height & Weight & Married & Education & Experience & headache & skin \\
\hline Age & 1 & & & & & & & \\
\hline Height & 0.3843 & 1 & & & & & & \\
\hline Weight & -0.3685 & -0.2418 & 1 & & & & & \\
\hline $\begin{array}{l}\text { Marital } \\
\text { status }\end{array}$ & -0.4113 & -0.14765 & 0.6105 & 1 & & & & \\
\hline Education & -0.3258 & -0.0726 & -0.4310 & -0.2631 & 1 & & & \\
\hline $\begin{array}{l}\text { Work } \\
\text { experience }\end{array}$ & -0.2117 & -0.2919 & -0.0792 & -0.0483 & 0.17844 & 1 & & \\
\hline $\begin{array}{l}\text { Headache } \\
\text { and body } \\
\text { ache }\end{array}$ & -0.2267 & -0.3127 & -0.0849 & -0.0518 & 0.19117 & -0.1024 & 1 & \\
\hline $\begin{array}{l}\text { Skin related } \\
\text { problems }\end{array}$ & -0.9556 & -0.3706 & 0.20386 & 0.12446 & 0.43968 & 0.24604 & 0.26358 & 1 \\
\hline
\end{tabular}

Table.6 Factors determining women employment in the fish dressing unit

\begin{tabular}{|l|c|c|}
\hline Variable & Co-efficient & S.E \\
\hline Age & -2.351 & 0.2376 \\
\hline Height & 0.525 & 0.010333 \\
\hline Weight & 0.542 & 0.01852 \\
\hline Marital status & 3.443 & 0.019 \\
\hline Education & 0.256 & 0.1208 \\
\hline Work experience & 0.184 & 0.0453 \\
\hline Headache and body ache & -0.343 & 0.0173 \\
\hline Skin related problems & -0.59 & 0.0185 \\
\hline -2 Log likelihood ratio - 14.721 & & \\
*Significant at 1\% level. & & \\
\hline
\end{tabular}


Table.7 Subject opinion about adaptability of gloves

\begin{tabular}{|c|c|c|c|c|c|c|c|}
\hline Gloves & : & 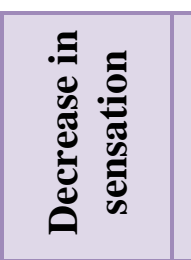 & 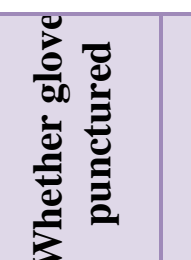 & 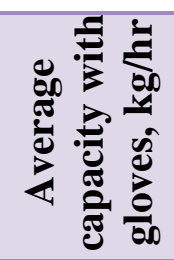 & $\stackrel{\Xi}{\Xi}$ & 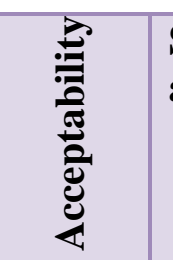 & $\begin{array}{l}\text { Subject opinion about } \\
\text { adaptability of finger coats }\end{array}$ \\
\hline $\begin{array}{l}\text { Finger } \\
\text { coats }\end{array}$ & $\begin{array}{l}\text { Yes- } \\
100 \%\end{array}$ & $\begin{array}{l}\text { Less } \\
\text { sensation }\end{array}$ & \begin{tabular}{|l|} 
Not \\
punctured \\
$-90 \%$ \\
Punctured \\
$10 \%$
\end{tabular} & 31.8 & $\begin{array}{l}\text { Yes-50\% } \\
\text { No-50\% }\end{array}$ & $\begin{array}{l}\text { Not } \\
\text { accepted }\end{array}$ & $\begin{array}{l}\text { It is not accepted due to water } \\
\text { accumulated in side finger } \\
\text { coats and it is difficult to } \\
\text { handle fish for dressing. } \\
\text { Injuries due fish spines } \\
\text { impregnation. }\end{array}$ \\
\hline $\begin{array}{l}\text { Medical } \\
\text { examinatio } \\
\text { n gloves }\end{array}$ & $\begin{array}{l}\text { Yes - } \\
50 \% \\
\text { No- } \\
50 \%\end{array}$ & Very high & $\begin{array}{l}\text { Punctured } \\
-50 \% \\
\text { Not } \\
\text { punctured } \\
-50 \%\end{array}$ & 34.45 & $\begin{array}{l}\text { Yes- } 40 \% \\
\text { No-60\% }\end{array}$ & $\begin{array}{c}\text { Not } \\
\text { accepted }\end{array}$ & $\begin{array}{l}\text { It protects whole fingers and } \\
\text { palm of hand but it give low } \\
\text { yield and get punctured, water } \\
\text { get enter and difficult to work. }\end{array}$ \\
\hline $\begin{array}{l}\text { Sterile } \\
\text { surgical } \\
\text { gloves }\end{array}$ & $\begin{array}{l}\text { Yes- } \\
20 \% \\
\text { No- } \\
80 \%\end{array}$ & Very high & $\begin{array}{l}\text { Punctured } \\
-30 \% \\
\text { Not } \\
\text { Punctured } \\
-70 \%\end{array}$ & 36.7 & $\begin{array}{l}\text { Yes-30\% } \\
\text { No-70\% }\end{array}$ & $\begin{array}{l}\text { Not } \\
\text { accepted }\end{array}$ & $\begin{array}{l}\text { It is well suited for hands but } \\
\text { fish slip in during dressing, it } \\
\text { protects hand, fearing cutting } \\
\text { and fish slip in hand during } \\
\text { dressing operation }\end{array}$ \\
\hline $\begin{array}{l}\text { Cotton } \\
\text { gloves }\end{array}$ & $\begin{array}{l}\text { Yes - } \\
100 \%\end{array}$ & Moderate & $\begin{array}{l}\text { Not } \\
\text { Punctured } \\
-100 \%\end{array}$ & 38.7 & No-70\% & $\begin{array}{l}\text { Not } \\
\text { accepted }\end{array}$ & $\begin{array}{l}\text { It absorbed water, hand get } \\
\text { wetted and difficult in } \\
\text { dressing. Fish spines get } \\
\text { impregnated. }\end{array}$ \\
\hline $\begin{array}{l}\text { Medical } \\
\text { (inside) + } \\
\text { cotton } \\
\text { gloves } \\
\text { (outer side) }\end{array}$ & $\begin{array}{l}\text { No- } \\
100 \%\end{array}$ & $\begin{array}{l}\text { Moderate - } \\
100 \%\end{array}$ & $\begin{array}{l}\text { Not } \\
\text { punctured } \\
-100 \%\end{array}$ & 42.4 & No- $100 \%$ & $\begin{array}{l}\text { Accepte } \\
\text { d }\end{array}$ & $\begin{array}{l}\text { It is well suited for hands, } \\
\text { good grip, easy to handle fish } \\
\text { for dressing. Water is not } \\
\text { enter in side due to inner } \\
\text { medical gloves. Dressing is } \\
\text { very fast. }\end{array}$ \\
\hline
\end{tabular}

Fish dressing capacity with hand protection gloves

The mean working capacity of ten selected subjects for fish dressing with modified method with different type of hand protection devices viz. finger coats (A), medical examination gloves (B), sterile surgical gloves
(C), cotton gloves (D) and combination of medical examination + cotton gloves (E) was $36.5,36.55,31.8,34.45,36.7,38.7,42.4$ $\mathrm{kg} / \mathrm{hr}$, respectively (Fig. 1 and 2). The highest mean working capacity was found for combination of medical examination gloves (in side) and cotton gloves as $42.4 \mathrm{~kg} / \mathrm{hr}(\mathrm{P}$ $<0.05$ ) with more acceptability, very fast to 
work, no pain and injuries to hands. Whereas finger coats (C) had lowest mean working capacity as $31.8 \mathrm{~kg} / \mathrm{hr}$ with less acceptability, hard to work, pain and injuries to hand. The subject opinion about gloves adaptability is given in Table 3.

One way ANOVA showed significant difference $(p<0.05)$ between the different types of hand protection devices used for fish dressing operation. Further result of StudentNewman-Keuls (SNK) test indicated that mean working capacity of subjects with the use of combination of medical examination gloves (outside) and cotton gloves (inside) were significantly $(\mathrm{p}<0.05)$ different from other gloves (Table 6).

Chang and Shih (2007) reported that one of the goals of wearing gloves is to protect the hands from contact with cold/hot objects. The wearing gloves not only reduce the pain but also delay a decrease in finger skin temperature (FST) (Suizu et al., 2004 and Suizu and Harada, 2005). Shih et al., (2007) observed that wearing gloves is able to prolong the exposure time in a cold environment, and this actually delays the harmful impact from the cold directly. Nag and Nag (2007) investigated the use of gloves and most of the workers reported a feeling of comfort and protection from direct contact with ice-cold chlorinated water. According to Shih and Wang, 2007 that wearing gloves can delay the heat exchange and prolongs the time of exposure of the hand in $10^{\circ} \mathrm{C}$ water. Wearing gloves could prolong the endurance time (ET) to reach a given finger skin temperature (FST) (Clark and Cohen, 1960) or delay the reduction in finger skin temperature (FST) at a given endurance time (Suizu et al., 2004). Similarly Pagarkar et al., (2014) studied effect of three different types of hand protection devices viz., finger coats, medical examination and sterile surgical gloves on the working capacity and performance suitability of women workers during fish dressing operation and revealed that sterile surgical gloves showed better working capacity as compared to other hand protection devices due to hand suitability, good grip, easy to handle fish during dressing operation.

Several epidemiologic studies have shown that, in addition to heavy physical work, awkward and static postures, repetition of movements, and vibration, cold may be a risk factor for occurrence or aggravation of musculoskeletal disorders (MSDs), such as in the fish-processing industry (Chiang et al., 1993 and Nordander et al., 1999). In addition, Nag and Nag (2007) who evaluated the hazards and health complaints associated with fish processing activities in India, indicated that, during a 2-hour period of work, wearing latex gloves could improve the FST and HST, raising morale in female workers, and alleviate cold-induced symptoms, because of the delay on FST decrease and reduction in perceived pain.

In the present study, during fish dressing operation wetting of hands, deceased in sensation and unacceptability by subjects was observed more in finger coats (A) followed by cotton gloves (D), medical examination gloves (B), sterile surgical gloves. The use the finger coats (A) in fish dressing operation showed that the hand of workers comes in continues contact with cold water and hand got wetted as water enters and accumulated inside the finger coats (A) and its makes finger coats (A) more slippery during fish dressing operation. A finger coats (A) only protects the finger, but hand is unprotected. Therefore, $50 \%$ hand injuries were reported during fish dressing operation making fish dressing operation more difficult, time consuming and unacceptable. The use of the medical examination gloves (D), sterile surgical gloves (E) showed that they protects fingers and hands of women workers from ice, cold water but fish slips 
during handing and dressing operation. Both gloves showed wetting of hand due to the entry of water through punched places and affecting the overall fish dressing capacity of subjects. In case of cotton gloves (F), it protects the hands from injuries, but not from cold chlorinated water. Cotton gloves (F) absorbed more water and became heavier and hand got wetted making fish handing and dressing operation difficult. Combination of medical examination (outside) and cotton gloves (inside) showed neither punctured nor hand injuries as cotton gloves protected hands injuries from fish spine impregnation, provided good grip, avoiding slips during the handling and dressing operation. It also acted as an insulator (Table 7).

Fish processing workers had high prevalence of, loss of hand sensation musculoskeletal disorders due to poor working facilities. Wearing gloves as an insulator can protect the hand in cold water and decrease the speed of heat dissipation. Our study confirmed that factors such as quality and type of material used for hand protection, working duration and environment are mostly associated with this. Hence the results of this study show that wearing gloves can insulate the hand in cold water. Also women workers after providing different types of gloves and showed more acceptability, highest capacity, very fast work and no hand wetting, hand sensation injuries for combination of medical examination gloves (in side) and cotton gloves as compared to finger coats, medical examination gloves, sterile surgical gloves, cotton gloves. It was also observed that use of combination of medical examination gloves (in side) and cotton gloves also protected the workers hands from numbness of fingers, peeling of hands, cold and cold related problems and increased the dexterity. Therefore, combination of medical examination gloves (in side) and cotton gloves (outer side) is recommended as first line of defense for fish dressing workers.

\section{Acknowledgement}

The authors are thankful to University authorities of Dr. B. S. Kokan Krishi Vidyapeeth, Dapoli, authorities of College of Agriculture Engg. and Technology, Dapoli and College of Fisheries, Ratnagiri and Project Coordinator, All India Coordinated Research Project on Ergonomics, Indian Council for Agricultural Research, New Delhi, for their encouragement and providing necessary facilities for the present work.

\section{References}

Almazan, C.V., Trienekens, J.H., and Bijman, J. 2011. Sustainable contracts in the Bottled Tawilis value chain in Taal, Batangas, Philippines. Int. J. Food System Dynamics. 2(4): 420-430.

Bhattacherjee A, Chau N, Sierra CO, Legras B, Benamghar L, Michaely JP, Ghosh AK, Guillemin F, Ravaud J F., and Mur J M 2003. Relationships of job and some individual characteristics to occupational injuries in employed people: a community-based study. Journal Occupation Health. 45(6):38291.

Chang, C.H., and Shih, Y.C. 2007. The effects of glove thickness and work load on female hand performance and fatigue during an infrequent high-intensity gripping task. Applied Ergonomics. 38(3): 317-324.

Chiang H, Ko Y, Chen S, Yu H, Wu T., and Chang P. 1993 Prevalence of shoulder and upper limb disorders among workers in the fish processing industry. Scand J Work Environ Health. 19 (2):126-31.

Enander, A., 1984. Performance and sensory aspects of work in cold environments: A Review. Ergonomics. 27: 365-378.

Enander, A. E., and Hygge, S. 1990. Thermal stress and human performance. 
Scandinavian Journal of work Environment and Health. 16(1): 44-50.

Ghosh, A.K, Bhattacherjee, A., and Chau, N. 2004. Relationships of working conditions and individual characteristics to occupational injuries: a case-control study in coal miners. $\mathbf{J}$ Occup Health. 46 (6):470-80.

Goonetilleke, R. S., and Hoffmann, E. R.2009. Hand-skin temperature and tracking

performance. International Journal of Industrial Ergonomics. 39(4): 590-595.

Heus R., Daanen H. A. M., and Havenith G. 1995. Physiological criteria for functioning of hands in the cold: A Review. Applied Ergonomics. 26(1): 5-13.

Jeyanthi P., Gopal Nikita, Murthy L. N. and Geethalakshmi, V.2015. Employment status of women in the seafood processing sector of Gujarat. Fishery Technology. 52: 135 - 139.

Kouser, R., Qureshi, S., Shahzad, F.A., and Hasan, H. 2012. Factors influencing the customer's satisfaction and switching behavior in cellular services of Pakistan, Int. J. Res. Busi. 2(1): 1525.

Nag, P.K., and Nag A. 2007. Hazards and health. Complaints associated with fish processing activities in IndiaEvaluation of a low-cost intervention. International Journal of Industrial Ergonomics. 37: 125-132.

Nordander, Catarina., Kerstina, Ohlsson.., Istvan, Balogh, Lars, Rylander., Birgitta, Palsson., and Staffan, Skerfving. 1999. Fish processing work: the impact of two sex dependent exposure profiles on musculoskeletal health, Occup. Environ. Med. 56:256264.

Ohlsson, K., Hansson, G., Balogh, I., Stromberg, U., Palsson, B., Nordander, C., Rylander, L. and Skerfving, S. (1994). Disorders of the neck and upper limbs in women in the fish processing industry. Occupational and Environmental Medicine, 51:826-832.

Olafsdottir, H. and Rafnsson, V. (2000) Musculoskeletal symptoms among women currently and formerly working in fish-filleting plants. Int. $J$ of Occupational and Environment Health.,6(1): 44-49.

Pagarkar, A. U., Shaikh, S.M., Aware, V.V., Shirsat N.A., and Patil, S.V. (2014) Studies on performance of finger coats, medical gloves and surgical gloves on women workers for fish dressing operation in seafood processing industries. Journal of Ecology, Environment and Conservation., 429433.

Riley, M. W., and Cochran, D. J. (1984) Dexterity performance and reduced ambient temperature. Human Factors, 26: 207-214.

Saha, Asim, Nag, Anjali and Nag, Pranab Kumar. (2006) Occupational injury proneness in Indian women: A survey in fish processing industries. Journal of Occupational Medicine and Toxicology, 1: 23 1-5.

Schieffer, R.E., Kok, R., Lewis, M.I., and Meese, G.B. (1984) Finger skin temperature and manual dexterity; some inter-group difference. Applied Ergonomics, 15(2): 135-141.

Shaikh, S.M., Pagarkar, A.U., Aware, V.V. and Kulkarni, G.N. (2016) Occupational health hazards in seafood industries, Proceedings of 2 nd National Conference on Recent Advances in Science and Technology, 2k16 (RAST-2k16), Organized by Finolex Academy of Management and Technology, Ratnagiri, Maharashtra, 17-18 Feb. 2016, 470-475. ISBN : 978-93-83046-31-7.

Suizu, K., Inoue, M., Fujimura, T., Morita, H., Inagaki, J., Kan, H., and Harada, N. 
(2004). Influence of waterproof covering on finger skin temperature and hand pain during immersion test for diagnosing hand-arm vibration syndrome. Industrial Health, 42:79-82.

Suizu, K. and Harada, N. (2005). Effects of waterproof covering on hand immersion tests using water at $10^{\circ} \mathrm{C}$, $12^{\circ} \mathrm{C}$ and $15^{\circ} \mathrm{C}$ for diagnosis of handarm vibration syndrome. International Archives Occupation Environment Health, 78: 311-318.
Tinashe, M.V., Edward, M.P., Dadirayil, M., Never, M., Godfrey, C., Joseph, M. and Joseph, C. (2013) An analysis of the factors influencing the smallholder communal cotton farmers' decision to adopt contract farming- A case of Zaka district. Bull. Env. Pharmacol. Life Sci. 2 (6): 131-134.

Zar, J.H. (2004). In: Biostatistical Analysis, Pearson Education, Inc., Dorling Kindersley (India) Pvt. Ltd., 663pp.

\section{How to cite this article:}

Shaikh, S.M., A.U. Pagarkar and Abhay Kumar. 2019. Studies on Performance of Different Type of Hand Protection Devices on Women Workers for Fish Dressing Operation in Seafood Processing Industries. Int.J.Curr.Microbiol.App.Sci. 8(11): 715-727.

doi: https://doi.org/10.20546/ijcmas.2019.811.086 